\title{
The Effectiveness of the Chemistry PBL Method via Facebook on the Soft Skills of College Students
}

\author{
Mohd Shahir Mohamed Sunar' ${ }^{1}$ \\ Ahmad Jelani Shaari ${ }^{2}$ \\ 'MARA College Kuala Nerang, Kuala Nerang Kedah, Malaysia \\ Email:shahir.sunar@mara.gov.my Tel: +6047867255 \\ ${ }^{2}$ Faculty of Education and Modern Languages, Northern University of Malaysia (UUM), Malaysia \\ Email: jelani@uum.edu.my
}

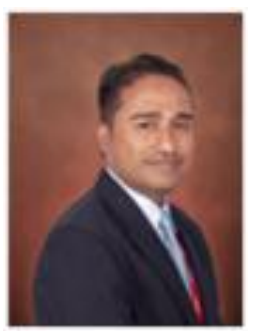

( Corresponding Author)

\begin{abstract}
It is undeniable that social media such as Facebook has such a great influence in all fields, including education. The main objective of this research is to study the interaction effects of the VARK learning style and students' learning approach on the development of their soft skills using the Problem-Based Learning (PBL) methods via Facebook in learning chemistry. The research sample consists of 120 Kolej MARA students who were randomly selected to undergo PBL via Facebook treatment for nine weeks. This quantitative research uses experiment design with descriptive and factorial 4x2 (Two-Way ANOVA) data analysis. The descriptive data analysis result finds that the problem-based learning method via Facebook is successful in developing soft skill elements such as communication skills, teamwork and leadership skills, problem-solving skills, self-ethics and moral worth, and continuous learning and information management skills. For the Two-Way ANOVA analysis, the main effects studied are the VARK learning style and the students' learning approach, as well as the interaction of the two towards the development of the students' soft skills after they were involved in problem-based learning method via Facebook. Test results show that the main effect of the VARK learning style on the development of their soft skills is insignificant across the students' learning approach using problem-based learning method via Facebook. The same goes for the main effect of the learning approach, which is also insignificant across the students' VARK learning style. The interaction effect between both free variables (VARK learning style and learning approach) on the development of soft skills is also found to be insignificant.
\end{abstract}

Keywords: VARK learning style, Deep learning approach, Surface learning approach, Problem-based learning method, Soft skills.

Citation | Mohd Shahir Mohamed Sunar; Ahmad Jelani Shaari (2017). The Effectiveness of the Chemistry PBL Method via Facebook on the Soft Skills of College Students. Asian Journal of Education and Training, 3(2): 97-104.

History:

Received: 18 October 2017

Revised: 9 November 2017

Accepted: 13 November 2017

Published: 16 November 201

Licensed: This work is licensed under a Creative Commons

Attribution 3.0 License (c)

Publisher:Asian Online Journal Publishing Group
Contribution/Acknowledgement: Both authors contributed to the conception and design of the study.

Funding: This study received no specific financial support

Competing Interests: The authors declare that they have no conflict of interests.

interests. Transparency: The authors confirm that the manuscript is an honest,
accurate, and transparent account of the study was reported; that no vital features of the study have been omitted; and that any discrepancies from the study as planned have been explained.

Ethical: This study follows all ethical practices during writing.

\section{Contents}

1. Introduction

2. Literature Review

3. Methodology

4. Findings

5. Discussion and Conclusion.

References.. 103 


\section{Introduction}

The widespread use and influence of Facebook, Twitter, WhatsApp and Telegram in our daily lives is undeniable, even causing the transformation to happen in all aspects of life such as politics, economy, education, social, method of getting information and even the working culture (Boyd and Ellison, 2008). Facebook emerged as the most popular social media platform in the world within a short period, reaching up to 500 million active users in July 2010, only six years after its inception (Paul, 2010). The number continued to rise and on 4 October 2012, the number of Facebook users reached 1 billion (Facebook.com, 2012). As of 27 June 2017, Facebook announced that there are 2 billion active users on Facebook (Facebook.com, 2017). Social media applications such as Facebook caught the attention of researchers across various sectors or fields, with education being one of them (Alexander, 2006; Lateh, 2014). It is also observed that social media has a huge potential in catering the needs of students today (Manca and Ranieri, 2013) since its use is suitable for students with their own learning styles and approach, and they are able to increase their learning experience through self-adjustment, increase their self-confidence and have a bigger opportunity or space to build their network and collaborations (Bryant, 2006; Mao, 2014). According to Hwang et al. (2004) social media need to be given due consideration to be integrated into the college or university education system, since the learning environment itself is a social system that allows students to interact with each other within the context of education. Furthermore, some research done in term of the perception found that social media usage in education is able to create a network of interaction, collaboration, sharing of resources, active participation and also critical thinking among students (Ajjan, 2008; Tess, 2013). However, there is a lack of past research that studied the effectiveness of social media as a tool, taking into consideration the students' background such as their learning styles and approach, the suitable pedagogy type and their learning methods. This shows that the scope of this research has yet to be studied in depth (Sobaih et al., 2016). However, based on the research by (Aghili et al., 2014) the implementation of social media integrated learning using active and contemporary learning methods such as problem-based learning (PBL) is expected to raise the level of thinking and develop deeper knowledge among students. Besides, such learning method has the potential in developing soft skill elements that the students need (Tess, 2013). We cannot deny the fact that every student must possess soft skills along with good academic achievement (Yahya, 2004; Ministry of Higher Education, 2006). According to Kamsah (2004) one of the reasons of university graduates marketability failure in the job market is because they are lacking in soft skills. The Ministry of Higher Education is aware of this issue and they are seriously looking into it by developing a soft skill development module for students in institutes of higher learning in Malaysia (MHE, 2006).

\section{Literature Review}

\subsection{Social Learning Theory and Sociocultural Learning Theory}

The suitability of social media such as Facebook for the integration into the teaching and learning process is based on two famous social learning theories, i.e. Social Learning Theory (Bandura, 1977) and Sociocultural Learning Theory (Vygotsky, 1978). Social Learning Theory emphasized on learning interaction with friends by looking at learning as a social process where each individual will interact with their peers, their models and their surrounding situation.

On the other hand, the Sociocultural Learning Theory states that the learning process must give more focus on social, language and cultural interaction. This theory emphasizes on a learning process that is not only seen as a process involving individuals, but it is also an individual development process in a social environment sphere (Hung, 2002).

\subsection{Learning Approach}

Learning approach is a concept that explains a student's acceptance and perception of a given subject or assignment (Ramsden, 1992). According to Watkins (1982) there are two types of learning approaches - the deep learning approach and the surface learning approach. If the student has a positive perception on a subject, they will adopt a deep learning approach, but on the other hand, if they have a negative perception on a subject, they will adopt a surface learning approach (Ramsden, 1992). The student will consciously pick a deep or surface learning method, and the implication of the choice is important in determining the results of the student's achievement, apart from the learning method used (Biggs et al., 2001). This is because the learning approach is a basic concept that takes into consideration the learning process and the quality of the learning results (Duff et al., 2004).

\subsection{The VARK Learning Style}

Learning style refers to the ways or methods that are usually applied in students' individual learning process (Hawk and Shah, 2007). According to the Ministry of Education Malaysia (2008) there are two types of learning style models that are frequently used in national level research, namely the VARK Learning Style Model and Dunn \& Dunn. This is because both learning style models have moderately high validity and credibility support values, and accessible as they are web-based (Hawk and Shah, 2007). The VARK Learning Style Model classified students into four different learning styles modes, based on different sensory inclinations known as Visual (V), Aural (A), Read \& Write $(\mathrm{R})$ and Kinaesthetic $(\mathrm{K})$.

\subsection{Soft Skills}

Soft skills refer to behavioural skill elements such as problem-solving, analyzing, working in a team, handling new problems, communicating through writing and having the ability to plan their work (Wilson and Lizzio, 1997). Having soft skills is a critical factor and given high priority for a university graduate to get hired in a sector. However, based on the report by the MHE (2006) there have been complaints that questioned the deterioration of the students' skillsets as the result of the current education system, especially that related to communications, leadership and self-identity, despite being a university graduate and recognized intellectually. One of the reasons graduates of higher learning institutions fail to secure positions in the job market is because they lack soft skills (Hasliza, 2002). MHE (2006) has set seven main elements of soft skills to be implemented in institutions of higher learning and mastered by students, namely communication skills, critical thinking and problem-solving skills, 
teamwork skills, continuous learning and information management, entrepreneurial skills, professional ethics and moral, and leadership skills. For the purpose of this research, the entrepreneurial skill element is not included since it is beyond the research context, which is to study the soft skills values that can be instilled when social media is integrated into teaching and learning.

\subsection{Problem-Based Learning (PBL)}

Problem-based learning was introduced by Howard S. Barrows and was first implemented at McMaster University in the medical field circa the 1960s (Barrows and Tamblyn, 1980). It started with the medical field and now it is widely used in other fields in almost all universities around the world. In developed countries such as the United States of America, problem-based learning is not only practised in university but also introduced in secondary schools from as early as the 1990s (Barrows and Kelson, 1993).

The problem-based learning method is also familiar to most students in Malaysian public and private universities. However, a research done by Tan and Mohammad (2014) found that this method is not widely practised in most universities in Malaysia, even though the method has been a common knowledge for a while. Most university students were only introduced to problem-based learning when they enter university (Tan and Mohammad, 2014). In other words, this method was not exposed to students during their secondary school years and even during their pre-university programmes such as Sijil Tinggi Pelajaran Malaysia (STPM), matriculation or A-Levels (Hussain and Berhannudin, 2009; Tan and Mohammad, 2014). In fact, most students and teachers in Malaysian secondary schools have never thought of or even know about problem-based learning and how to implement them (Faaizah and Halimah, 2007).

Initially, the idea to implement problem-based learning surfaced when it was found that most medical students at that time fail to apply their knowledge in the actual clinical environment, despite getting excellent results in their finals. Problem-based learning was developed in an effort to prep students with a learning environment that is similar to actual clinical environment or practice. This kind of learning environment would be able to equip students with skills relevant in the real world as well as encouraging the students to adopt a deeper learning (Tan and Mohammad, 2014).

\subsection{Blended Learning Model through Social Media via Problem-Based Learning}

The problem-based learning method has gone through various transformations, moving concurrently with the ever-evolving technology. The development of the Web 2.0 technology has allowed easier interaction and collaboration among students especially during the discussion process in order to find a solution to a certain problem (Treepuech, 2011; Sobaih et al., 2016). Social media (like Facebook), one of Web 2.0's most important technologies, has the potential to facilitate the implementation of the problem-based learning process (Wiboolyasarin, 2014). Further research has successfully developed learning models that utilised social media such as Facebook as a learning tool. For example, Blended Learning Model via Social Media using Problem-Based Learning (Wiboolyasarin, 2014) that has eight levels of learning, which are preparing, identifying, analysing, researching, creating, testing, gathering and evaluating.

Diagram 1.0 shows the flowchart of each activity based on the Social Media Blended Learning Model based on Problem Solving Methods.

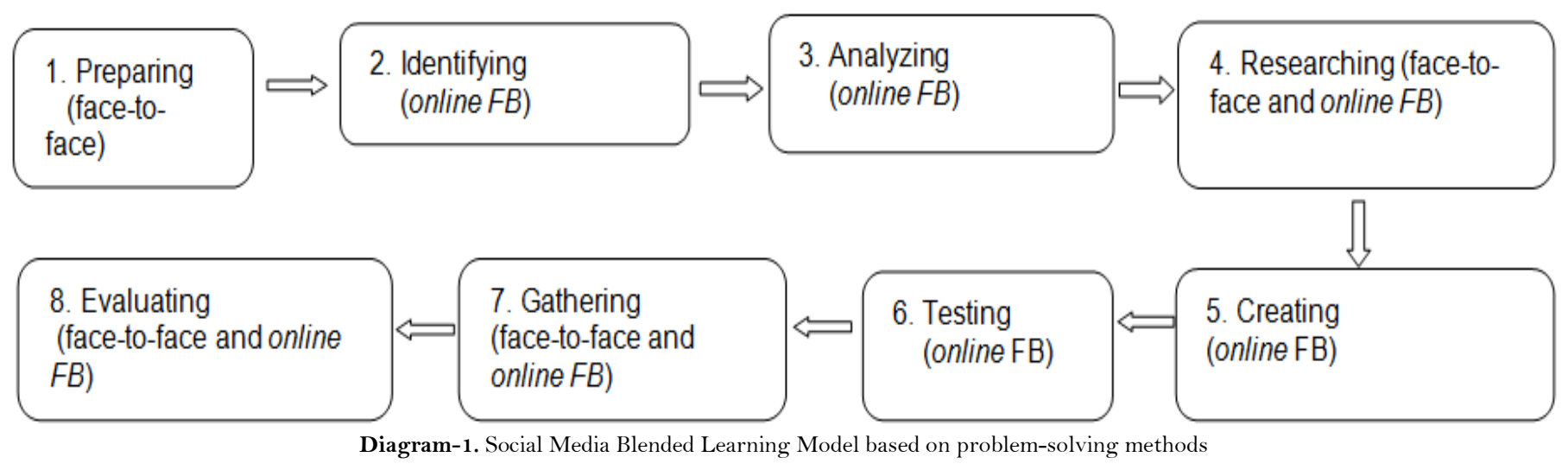

\subsection{Research Objective}

The research objectives are:

1. Identifying the soft skill levels of Kolej MARA students after receiving problem-based learning method via Facebook treatment.

2. Identifying the effects of the Kolej MARA students' learning styles (Visual, Aural, Read \& Write and Kinesthetic) on their soft skills across the students' learning approach (surface and deep) using problembased learning method via Facebook.

Main effect $A$ )

3. Identifying the effects of the Kolej MARA students' learning approach (surface and deep) on their soft skills across students' learning styles (Visual, Aural, Read \& Write and Kinesthetic) using problem-based learning method via Facebook.

\section{(Main effect B)}

4. Identifying the interaction effects of the students' learning styles (Visual, Aural, Read \& Write and Kinesthetic) on the soft skills of Kolej MARA students who adopted the learning approach (surface and deep) using problem-based learning method via Facebook.

(Interaction effect $A \times B$ ) 


\subsection{Research Hypothesis}

Three null hypotheses were formulated based on the research objectives. The first research objective did not have a hypothesis because the analysis was done descriptively.

First Hypothesis: There is no significant difference in the effect of students' learning style (Visual, Aural, Read \& Write and Kinaesthetic) on the soft skills of Kolej MARA students across their learning approach (deep and surface) using the problem-based learning method via Facebook.

Second Hypothesis: There is no significant difference in the effect of students' learning approach (deep and surface) on the soft skills of Kolej MARA students across their learning styles (Visual, Aural, Read \& Write and Kinaesthetic) using the problem-based learning method via Facebook.

Third Hypothesis: There is no significant difference in the effect of students' learning style interaction (Visual, Aural, Read \& Write and Kinaesthetic) on the soft skills of Kolej MARA students who adopted the learning approach (deep and surface) using the problem-based learning method via Facebook.

\section{Methodology}

\subsection{Research Design}

This research utilised the quantitative method using the $4 \times 2$ factorial experiment design. The main effects studied are the VARK (Visual, Aural, Read \& Write and Kinaesthetic) learning styles and learning approach (deep and surface). The result of the interaction between the two variables was measured by the development of the students' soft skills after undergoing problem-based learning methods via Facebook.

\subsection{Sampling Technique}

This research utilised the stratified random sampling method. The students were asked to answer the learning approach instrument while the VARK learning style was carried out online. Each student was then classified according to the two learning styles and approach and later randomly picked (was assigned the treatment at random) to receive treatment on problem-based learning methods via Facebook in smaller groups. The gender factor was also taken into consideration so each small group formed will have a balance of both males and females. There were eight treatment groups formed of 15 students who were randomly picked (refer to Table 1). The total number of students who took part in this research is 120 respondents of 58 male students and 62 female students.

Table-1. Research Group

\begin{tabular}{|c|c|c|c|}
\hline \multicolumn{2}{|c|}{ Number of Students } & \multirow{2}{*}{$\begin{array}{l}\text { Learning Approach } \\
\text { Surface }\end{array}$} & \multirow{2}{*}{$\begin{array}{l}\text { VARK Learning Style } \\
\text { Visual }\end{array}$} \\
\hline 1. & 15 & & \\
\hline 2. & 15 & Surface & Aural \\
\hline 3. & 15 & Surface & Reading \& Writing \\
\hline 4. & 15 & Surface & Kinaesthetic \\
\hline 5. & 15 & Deep & Visual \\
\hline 6. & 15 & Deep & Aural \\
\hline 7. & 15 & Deep & Reading \& Writing \\
\hline 8. & 15 & Deep & Kinaesthetic \\
\hline
\end{tabular}

\subsection{Data Collection}

Data collection for this research involves problem-based learning activities for 11 Facebook groups of students, a survey on students' VARK learning style, students' learning approach and soft skills. Problem-based learning activities via Facebook was conducted for nine weeks, while the survey on VARK learning style and learning approach were given before the PBL via Facebook treatment was conducted. Then, a survey on soft skills was given to students after they have completed the treatment. The students' learning styles were measured using the VARK Learning Style Version 7.0 (Flemming and Charles, 2004) instrument that contains 16 items. This instrument was obtained online from the official VARK Learning Style official website. Students can answer the survey online and receive immediate results. Meanwhile, The Revised Two Factor Study Process Questionnaire RSPQ-2F (Biggs et al., 2001) instrument was used to measure the students' learning approach. Next, to measure the students' soft skills, the Course Experience Questionnaire (CEQ) (Wilson and Lizzio, 1997) instrument which has nine items, combined with an additional four items prepared by the researcher was utilised. The addition of the four items is to ensure that the soft skill elements measured were parallel with the soft skill elements suggested by the MHE (2006). This is because there are some elements suggested by the Ministry of Higher Education that are not included in the Course Experience Questionnaire (CEQ).

\subsection{Students' Facebook Chemistry PBL Group}

Students involved in this research were asked to join their respective Facebook groups as assigned by the lecturer. Problem-based learning (PBL) took place to include the lecturer who is also a member of the group, but the lecturer only acted as a facilitator and monitored every student's discussion. 

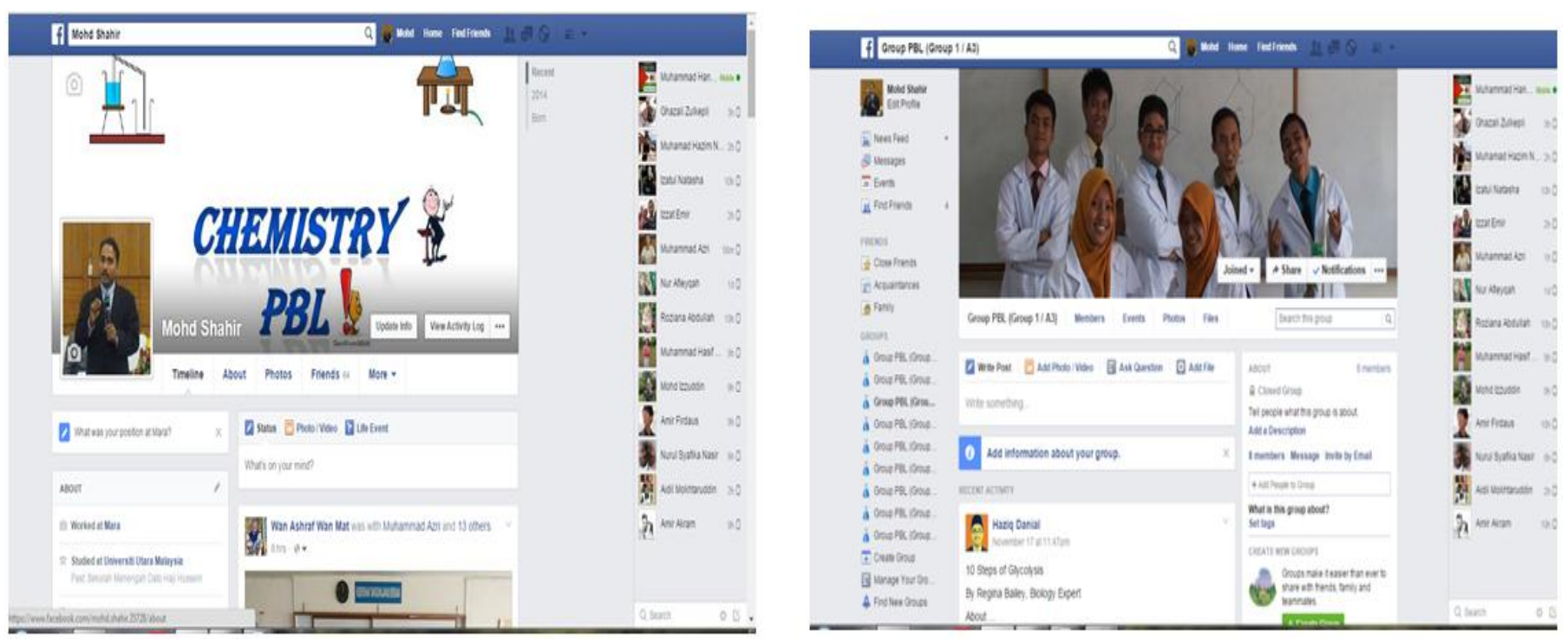

Diagram-1. Sample Front Page Display of One of the PBL Group's Discussion

\subsection{Research Procedure}

\section{Week One Till Eight}

i) Identifying the students learning style and approach

ii) Face-to-face instruction
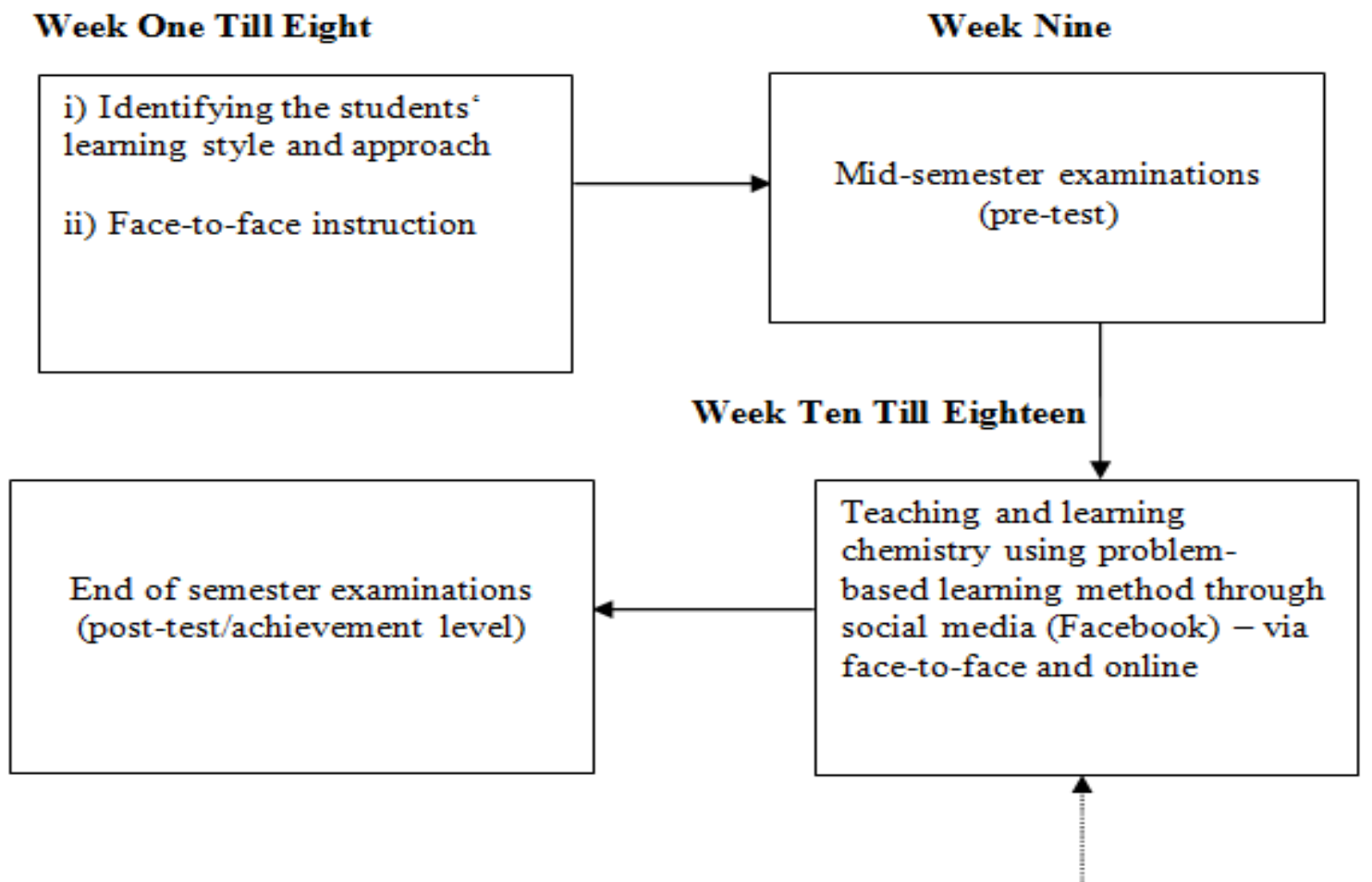

Student-lecturer interaction will happen via social media (lecturer will assist and monitor).

Diagram-2. Research Implementation Procedure

\subsection{Chemistry PBL via Facebook Learning Process}

The Chemistry PBL via Facebook Learning Process is based on the Blended Learning Model through Social Media via Problem-Based Learning that was introduced by Wiboolyasarin (2014). There are eight main phases based on the model, namely preparing, identifying, analyzing, researching, creating, testing, gathering and evaluating. The followings are the explanation for the activities in each phase, sorted by week:

1. Preparing (first week): During this stage, the lecturer explained the learning objectives, learning activities, evaluation process and communication means that could be done via Facebook. Problem scenarios were also given to each group and this activity is done face-to-face

2. Identifying (second week): Students were asked to study the problem's situation, to discuss, and to list down as many ideas to handle the problem. The activity was done online on Facebook.

3. Analyzing (third week): Planning to collaborate, doing job distribution, problem analysis and planning problem-solving. The activity was done online on Facebook.

4. Researching (fourth and fifth week): Students did their studying, searching, researching and information gathering from various sources. The activity was done face-to-face and online on Facebook.

5. Creating (sixth week): Students came up with their hypothesis based on information gathered and their existing knowledge and experience. The activity was done online on Facebook.

6. Hypothesis Testing (seventh week): Students discussed and exchanged information before the information was used to test the hypothesis. The activity was done online on Facebook.

7. Summarizing (eighth week): Each group was asked to do a summary of the ideas, approach and analysis done in solving a problem. Each report was uploaded onto the Chemistry PBL Facebook page and other 
team members gave their opinions and comments on the work of other groups. The activity was done faceto-face on Facebook.

8. Evaluating (ninth week): Each group presented their research findings (solution) to the problem statement received. Fellow students from other groups were allowed to voice their opinions. The lecturer gave his/her comments and evaluation, including on the cooperation of each team member in a group. The activity was done face-to-face and online on Facebook.

\section{Findings}

Findings obtained from the survey were analysed using the SPSS 19.0 software to get the mean score, percentage and standard deviation for each variable. The mean score for each variable was interpreted according to the scale range as in Table 2:

Table-2. Mean Score Interpretation for Each Variable

\begin{tabular}{l|l|l}
\hline Score & Mean Score Range & Mean Score Interpretation \\
\hline 1 & 1 to $\leq 1.80$ & Highly disagree \\
\hline 2 & $>1.80$ to $\leq 2.60$ & Disagree \\
\hline 3 & $>2.61$ to $\leq 3.40$ & Not sure \\
\hline 4 & $>3.41$ to $\leq 4.20$ & Agree \\
\hline 5 & $>4.21$ to $\leq 5.00$ & Highly agree \\
\hline
\end{tabular}

Descriptive analysis was used to analyze the first research objective while factorial analysis (Two-Way ANOVA) was used to test the second, third and fourth research objective.

\subsection{The Soft Skills Levels of Kolej MARA Students after Receiving the Problem-Based Learning} (PBL) Method via Facebook Treatment

The analysis was done to soft skills instruments given to 120 Kolej MARA students as soon as they completed problem-based learning method via Facebook. Based on descriptive statistics (Table 3), communication skills obtained the highest agreed value $((\mathrm{M}=3.92, \mathrm{SP}=0.33)$ as compared to other soft skills. This shows that most students agreed that problem-based learning method via Facebook is successful in developing effective communication skills among students. Overall, it was found that all Kolej MARA students agreed that problembased learning method via Facebook is successful in developing the soft skill elements needed especially in studying chemistry.

Table-3. Mean Score of Students' Soft Skill Aspect after Undergoing PBL via Facebook Treatment ( $\mathrm{n}=120)$

\begin{tabular}{l|l|l|l}
\hline Construct & Mean Score & Standard Deviation & $\begin{array}{l}\text { Mean Score } \\
\text { Interpretation }\end{array}$ \\
\hline Communication & 3.92 & 0.33 & Agree \\
\hline Teamwork and Leadership & 3.89 & 0.43 & Agree \\
\hline Problem Solving & 3.86 & 0.38 & Agree \\
\hline Self-Ethics and Moral Worth & 3.82 & 0.57 & Agree \\
\hline Continuous Learning and Information Management & 3.77 & 0.84 & Agree \\
\hline Total & $\mathbf{3 . 8 5}$ & $\mathbf{0 . 5 1}$ & Agree \\
\hline Source: Adapted from Nabilah $(2019)$ &
\end{tabular}

Source: Adapted from Nabilah (2012)

The next analysis was to study the main effect and interaction effect between two independent variables, the VARK learning style factor and learning approach adopted by the students, towards the development of soft skills. Table 4 shows the Two-Way ANOVA analysis findings.

Table-4. ANOVA Analysis on Learning Style and Learning Approach towards Soft Skill Development.

\begin{tabular}{l|l|l|l|c|c}
\hline Source & DF & PT & PTM & F & Sig \\
\hline Learning Style (A) & 3 & 0.80 & 0.27 & 0.98 & .405 \\
\hline Learning Approach (B) & 1 & 0.77 & 0.77 & 2.84 & .095 \\
\hline Learning Style*Learning Approach (A X B) & 3 & 0.211 & 0.07 & 0.26 & .855 \\
\hline Error & 112 & 30.363 & 0.27 & & \\
\hline Total & 120 & 1653.947 & & & \\
\hline *significance level 0.05 & & & \\
\hline $\begin{array}{l}\text { DF = Degree of Freedom PT = Power of Two PTM = Power of Two Mean } \\
\text { F = F Statistic Sig = Significance }\end{array}$
\end{tabular}

4.2. The Effect of Students' VARK Learning Style on the Development of Soft Skills across Their Learning Approach Using Problem-Based Learning (PBL) Method via Facebook

The ANOVA test result shows insignificant main effect of the learning style on soft skills, $\mathrm{F}(3,112)=0.98$, $\mathrm{p}>0.05$. This result failed to negate the first hypothesis, $\mathrm{H}_{\circ} 1$. This situation shows that the development of soft skills using problem-based learning method via Facebook is the same for visual, aural, read-write and kinaesthetic learning styles across students' learning approach that they adopted.

4.3. The Effect of Students' Learning Approach on the Development of Soft Skills across Their VARK Learning Style Using Problem-Based Learning (PBL) Method via Facebook

The ANOVA test result shows insignificant main effect of the learning approach (surface and deep) on soft skills, $\mathrm{F}(1,112)=2.84, \mathrm{p}>0.05$. This result failed to negate the second hypothesis, $\mathrm{H}_{\circ} 2$. This situation shows that 
the deep learning approach does not exhibit a significant difference towards the surface learning approach on the development of soft skills across students' learning styles using problem-based learning method via Facebook.

\subsection{The Effect of Students' VARK Learning Style on the Development of Soft Skills of Kolej MARA Students Who Adopted the Learning Approach (Surface and Deep) Using Problem-Based Learning (PBL) via Facebook Method}

The ANOVA test result shows insignificant effect of the interaction between the two variables, learning style and learning approach, on the soft skill dependent variable, $\mathrm{F}(3,112)=0.26, \mathrm{p}>0.05$. This result failed to negate the third hypothesis, $\mathrm{H}_{\circ}$.

\section{Discussion and Conclusion}

The descriptive analysis found that the soft skills mean factor value is 3.85 after students underwent problembased learning method via Facebook. This shows that students agree with the statements that test soft skill elements. In a study done to secondary school students by Nabilah (2012) the mean factor value comprising of elements set by the MHE (2006) is 3.57, which is slightly lower than this research. However, the research finding by Noor and Khoo (2010) shows that the level of soft skills with elements such as communication skills, teamwork, problem-solving, the ability to adjust in various situations, lifelong learning, self-efficacy, and self-moral and ethical values shows a higher mean at 4.21. There are a few possibilities that caused this research to have higher soft skills mean factor value as compared to the research by Nabilah (2012) but lower than the research done by Noor and Khoo (2010). One of the possibilities is the students' age and experience. The students who were involved in this study are pre-university students (secondary school leaver) as opposed to those involved in the study done by Nabilah (2012) who were the secondary school students. Meanwhile, the research by Noor and Khoo (2010) studied the soft skills levels of Universiti Teknologi Malaysia (UTM) final year students. Thus, it is possible that the students' soft skills levels increase with age and maturity, as well as the experience gained during the secondary school, pre-university and the university level.

Overall, findings obtained from Two-Way ANOVA factorial data analysis fail to negate the null hypothesis and does not have any similarities to most of the earlier research. For example, the research findings are not parallel to the research by Vijayalakshmi and Renuga (2012) which found a relationship between students' learning styles and soft skills through learning English literature. This can happen if the materials and learning methods were properly planned and took into consideration the suitable stimulus for visual, aural, read-write and kinaesthetic learning styles (Vijayalakshmi and Renuga, 2012). The research by Vijayalakshmi and Renuga (2012) also used the VARK learning style to measure the learning styles adopted by the students and some of the soft skills that can be applied are leadership qualities, interpersonal relationship, teamwork and stress management.

The research also found no difference in soft skills development between students who adopted surface learning approach and those who adopted the deep learning approach. The result is in line with the research done by Gijbels et al. (2005) that found no significant relationship between surface and deep learning approach with problem-solving skills (one of the soft skill elements). However, the findings are different from the findings of Lizzio et al. (2002) that found students who are more inclined towards deep learning approach could increase their soft skills compared to students who adopted the surface learning approach. The same goes to the qualitative study by Green (2007) that found students who adopted the surface learning approach have lesser command of several soft skills elements such as self-confidence, ability to present arguments and the ability to communicate as opposed to students who adopted the deep learning approach. Besides, the findings of this research contradict the findings by Nabilah (2012) where the deep learning approach has a significantly positive relationship with soft skills while the surface learning approach shows a significantly negative relationship with soft skills.

This research found that the development of soft skills elements could be done through problem-based learning via Facebook method, especially in chemistry. Based on feedback from the students, the three most effective soft skill elements developed from the learning method are communication skills, teamwork and leadership skills, and problem-solving skills. Hence, the problem-based learning via Facebook method especially in learning chemistry should begin at an earlier stage (for example, in the pre-university level). Other than being able to develop their soft skills much earlier, early exposure to problem-based learning could also help students to apply the knowledge or theories learnt in class into real-life situations. This early exposure could also be beneficial to the students by being familiar with the method before learning about it in the university. Since this research required the students to self-evaluate their level of soft skills, there is a tendency for them to rate themselves highly for each soft skills element. For future research, it is recommended that the soft skills rating to be done by another party that is truly authoritative, knows the student and are directly involved with the student throughout the learning process. For example, the group leader, group members or the lecturer who were involved in the learning process. In that way, the evaluation of the students' soft skills would be more accurate and not entirely dependent on their own perception.

\section{References}

Aghili, M., A.K. Palaniappan, K. Kamali, S. Aghabozorgi and S.A. Sardareh, 2014. Unifying informal and formal learning environments: Educational use of social network sites through implementing community of inquiry framework. International Journal of eEducation, e-Business, e-Management and e-Learning, 4(3): 191-196.

Ajjan, H., 2008. Investigating faculty decisions to adopt web 2.0 technologies: Theory and empirical tests. Internet and Higher Education, $11(2): 71-80$.

Alexander, B., 2006. Web 2.0: A new wave of innovation for teaching and learning? Educause Review, 41(2): 32-44.

Bandura, A., 1977. Social learning theory. Englewood Cliffs, New Jersey: Prentice-Hall.

Barrows, H.S. and A. Kelson, 1993. Problem-based learning in secondary education and the problem-based learning institute. Springfield, IL: Southern Illinois University School of Medicine.

Barrows, H.S. and R.M. Tamblyn, 1980. Problem-based learning: An approach to medical education. New York: Springer Publishing Company.

Biggs, J., D. Kember and D.Y.P. Leung, 2001. The revised two-factor study process questionnaire: R-SPQ-2F. British Journal of Educational Psychology, 71 (1): 133-149. DOI 10.1348/000709901158433. 
Boyd, D. and N. Ellison, 2008. Social network sites: Definition, history \& scholarship. Journal of Computer-Mediated Communication, 13(1): $210-230$.

Bryant, T., 2006. Social software in academia. Educause Journal Quarterly, 29(2): 61-64.

Duff, A., E. Boyle, K. Dunleavy and J. Ferguson, 2004. The relationship between personality, approach to learning and academic performance. Personality and Individual Differences, 36(8): 1907-1920.

Faaizah, S. and B.Z. Halimah, 2007. C2HADAM: Hybrid PBL multimedia and web based courseware for science. Paper Presented at the International Seminar on Science and Mathematics (CoSMEd), on 13-16 November 2007, at SEAMEO RECSAM, Penang, Malaysia.

Facebook.com, 2012. One billion people on facebook. Retrieved from http://newsroom.fb.com/News/457/One-Billion-People-on-Facebook.

Facebook.com, 2017. Facebook reports first quarter 2017 results. Retrieved from http://investor.fb.com/releasedetail.cfm?ReleaseID $=780093$.
$\quad$ N.D. and C.B. Charles, 2004. VARK, a guide to learning styles. Retrieved from http://edorigami.wikispaces.com/ICT+and+LEARNING+STYLES

Gijbels, D., G. Van de Watering, F. Dochy and P. Van den Bossche, 2005. The relationship between students' approaches to learning and the assessment of learning outcomes. European Journal of Psychology of Education, 20(4): 327-341.

Green, W., 2007. Write on or write off? An exploration of Asian international students' approaches to essay writing at an Australian university. Higher Education Research \& Development, 26(3): 329-344.

Hasliza, H., 2002. Characteristics of student quality for current job requirements. Paper Presented at Seminar Between Industry and Public Education Institution, on 20-22 October 2012, at Universiti Teknologi Malaysia.

Hawk, T.F. and A.J. Shah, 2007. Using learning style instruments to enhance student learning. Decision Sciences Journal of Innovative Education, 5(1): 1-19.

Hung, D., 2002. Bringing communities of practice into schools: Implications for instructional technologies from Vygotskian perspectives. International Journal of Instructional Media, 29(2): 171-183.

Hussain, O. and S.M. Berhannudin, 2009. First year students first year PBL experience in a large class. Paper Presented at PBL International Symposium 2009, on 10-12 June 2009, at Republic Polytechnic, Singapore.

Hwang, A., E.H. Kessler and A. Francesco, 2004. Student networking behavior, culture and grade performance: An empirical study and pedagogical recommendations. Academy of Management Learning and Education, 3(2): 139-150.

Kamsah, M.Z., 2004. Developing generic skills in classroom environment: Engineering students' perspective. Paper Presented at Conference On Engeneering Education (CEE 2004), Kuala Lumpur, pada 14-15 Disember 2004.

Lateh, A., 2014. Integrating facebook social network for the statistics course: Its outcomes of undergraduate students' Prince of Songkla University Pattani Campus, Thailand. Asian Social Science, 10(6): 212-219.

Lizzio, A., K. Wilson and R. Simons, 2002. University students' perceptions of the learning environment and academic outcomes: Implications for theory and practice. Studies in Higher Education, 27(1): 27-52.

Manca, S. and M. Ranieri, 2013. Is it a tool suitable for learning? A critical review of the literature on facebook as a technology-enhanced learning environment. Journal of Computer Assisted Learning, 29(6): 487-504.

Mao, J., 2014. Social media for learning: A mixed methods study on high school students' technology affordances and perspectives. Computers in Human Behavior, 33: 213-223. DOI 10.1016/j.chb.2014.01.002.

Ministry of Education Malaysia, 2008. Time management and learning style. Retrieved from http: //myschoolnet.ppk.kpm/my.bhn.pnp/modul/bcb9.

Ministry of Higher Education, 2006. Soft skills development module for Malaysian higher education institutions. Putrajaya.

Nabilah, H., 2012. The role of learning approach as a mediator of relationship between teacher teaching effectiveness with critical thinking and soft skills.

Noor, A.A. and V.L. Khoo, 2010. Implementing soft skills among teachers trainers who take computer science courses at faculty of education universiti teknologi Malaysia.

Paul, I., 2010. Facebook's half billion $\quad$ users: $\quad$ Fun facts. Retrieved from http://www.pcworld.com/article/201650/facebooks_half_billion_users_.

Ramsden, P., 1992. Learning to teach in higher education. London: Routledge.

Sobaih, A.E.E., M.A. Moustafa, P. Ghandforoush and M. Khan, 2016. To use or not to use? Social media in higher education in developing countries. Computers in Human Behavior, 58(1): 296-305.

Tan, Y.P. and Y.A. Mohammad, 2014. Teacher and student questions: A case study in Malaysian secondary school problem-based learning. Asian Social Science, 10(4): 174-182.

Tess, P.A., 2013. The role of social media in higher education classes (Real and Virtual) - a literature review. Journal of Computers in Human Behavior, 29(5): 60-68.

Treepuech, W., 2011. The application of using social networking sites with available online tools for teaching and learning management. Paper Presented IT in Medicine and Education (ITME) 2011, at the International Symposium, Sapporo, Japan, on 5-7 August 2011.

Vijayalakshmi, M.V. and M. Renuga, 2012. Trainers' tool: Adhering to VARK@ learning styles for tutoring students in soft skills through JK Rowling's Harry Potter and the chamber of secrets. Journal of Humanities And Social Science, 41(3): 2-12.

Vygotsky, L.S., 1978. Mind in society: The development of higher psychological processes. Cambridge, Massachusetts: Harvard University Press.

Watkins, D., 1982. Identifying the study process dimensions of Australian university students. Australian Journal of Education, 26(1): 76-84.

Wiboolyasarin, W., 2014. Blended problem-based instructional model via facebook application on mobile: Are you ready for m-learning? International Journal of e-Education, e-Business, e-Management and e-Learning, 4(2): 91-94.

Wiersma, W., 2000. Research methods in education: An introduction. 7th Edn., Boston: Allyn \& Bacon.

Wilson, K.L. and A. Lizzio, 1997. The development, validation and application of the course experience questionnaire. Studies in Higher Education, 22(1): 33-52.

Yahya, B., 2004. Integration of employability skills in industry and agriculture vocational education in Malaysia. PhD Thesis of Universiti Teknologi Malaysia. 